\title{
Pengembangan Usaha Mikro Kecil Dan Menengah Telor Asin Di Kelurahan Mojolangu Kota Malang
}

\author{
Ahmad Mukoffi ${ }^{1}$, Agustinus Soemardi Soebagio ${ }^{2}$ \\ Jurusan Akuntansi, Fakultas Ekonomi \\ Universitas Tribhuwana Tunggadewi \\ e-mail: unitriahmadmukoffi@gmail.com
}

\begin{abstract}
Abstrak
Meningkatnya permintaan telur asin di pasaran dapat mendorong minat masyarakat Kecamatan Lowokwaru khususnya Kelurahan Mojolangu untuk mengembangkan usahanya. Untuk mengembangkan usahanya, usaha kecil dan menengah memiliki kendala dalam melakukan proses produksi. Permasalahannya adalah lamanya proses produksi telur asin yang disebabkan oleh pembuatan telur asin dan pencucian telur asin masih tradisional berdampak pada tidak terpenuhinya kebutuhan konsumen. Selain permasalahan pada proses produksi usaha mikro kecil dan menengah, kurangnya pengetahuan dan pemahaman terhadap penyusunan laporan keuangan dan pembinaan strategi pemasaran. Inovasi pembuatan telur asin dan pencucian telur asin menggunakan mesin membantu usaha mikro kecil dan menengah untuk memenuhi kebutuhan konsumen secara tepat waktu dengan jangka waktu proses pengasinan maksimal 3 hari dalam satu kali produksi. Alat pencucian telur asin yang diperlukan untuk membersihkan abu gosok yang menempel pada permukaan cangkang telur kurang lebih memerlukan waktu 5 sampai 10 menit dalam satu kali proses pencucian. Pelaksanaan pelatihan penyusunan laporan keuangan dan pembinaan strategi pemasaran membantu usaha mikro kecil dan menengah mengukur kinerja perusahaan
\end{abstract}

Kata Kunci: Mesin Pembuat Telur Asin; Mesin Pencuci Telur Asin

\begin{abstract}
The increasing demand for salted eggs on the market can encourage the interest of the Lowokwaru Sub-district, especially the Mojolangu Sub-District, to develop its business. To expand its business, small and medium enterprises have problems in carrying out the production process. The problem is the length of the process of producing salted eggs caused by making salted eggs and washing salted eggs is still traditional has an impact on not meeting consumer needs. In addition to the problems in the production process of small and medium micro businesses, lack of knowledge and understanding of the preparation of financial reports and fostering marketing strategies.The innovation of making salted eggs and washing salted eggs using machines helps small and medium micro businesses to meet consumer needs in a timely manner with a maximum salting process period of 3 days in one production. The salted egg washing tool needed to clean the rubbing ash attached to the surface of the eggshell requires approximately 5 to 10 minutes in one washing process. The training of financial report preparation and marketing strategy development helps small and medium micro enterprises measure company performance.
\end{abstract}

Keywords: Salted Egg Making Machine; Salted Egg Washing Machine 


\section{PENDAHULUAN}

Kemiskinan yang terjadi di Indonesia menimbulkan tanggapan berbagai pihak baik dari lembaga swasta maupun lembaga lainnya. Setiap Program yang dilaksanakan untuk mengatasi permasalahan berupa kemiskinan namun masih belum menemukan solusi yang tepat untuk mengentaskan kemiskinan. Hal ini ditunjukkan oleh pemerintah Kota Malang yang berupaya untuk meningkatkan Produk Domestik Regional Bruto dengan cara mendirikan usaha kecil dan menengah. Salah satu upaya pemerintah untuk menyelesaikan kemiskinan adalah dengan memperhatikan Usaha Kecil Menengah (UKM) yaitu usaha yang sinergi antara pemerintah dengan pihak - pihak lain sangat dibutuhkan untuk efektivitas program pemberdayaan ${ }^{1}$.

Usaha telur asin merupakan usaha kecil dan menengah yang banyak diminati oleh masyarakat Kecamatan Lowokwaru. Banyaknya minat masyarakat Kecamatan Lowokwaru pada usaha telur asin seiring dengan tingginya permintaan telur asin di pasaran. Perusahaan dengan skala kecil dan menengah seringkali memiliki kendala dalam melakukan proses produksi. Salah satunya adalah keterbatasan modal yang dimiliki berdampak pada teknologi yang memadai dalam proses produksi. Kurangnya teknologi yang memadai menyebabkan banyaknya permintaan konsumen telur asin yang tidak terpenuhi.

Mitra sebagai salah satu pengusaha yang bergerak pada produksi telur asin. Adanya minat untuk menekuni usaha telur asin karena keterbatasan biaya hidup keluarga yang disebabkan oleh pemutusan hubungan kerja (PHK) terhadap suami yang bekerja di salah satu perusahaan Swasta. Upaya yang dilakukan mitra untuk menjalankan usaha telur asin dalam memenuhi kebutuhan konsumen yang tinggi masih belum maksimal karena proses produksi telur asin masih menggunakan peralatan yang tradisional.
Proses produksi telur asin masih tradisional dengan cara membersihkan telur menggunakan air terlebih dahulu dengan tujuan untuk menghilangkan noda dipermukaan telur. Kemudian keringkan telur baik menggunakan kain kering. Setelah kering maka di amplas agar pori - pori telur terbuka dan adonan untuk mengasinkan telur dapat meresap. Bungkus telur asin dengan menggunakan adonan berupa abu gosok lalu proses pemeraman telur selama beberapa hari. Pada saat pemeraman, mitra menggunakan wadah penyimpanan telur dengan kapasitas kecil dan proses pemeraman telur yang lama yaitu ; 10 hingga 15 hari, sehingga hal ini memerlukan inovasi teknologi produk untuk mempercepat proses pengasinan. Selain wadah yang kecil pada saat pemeraman telur asin, mitra juga membersihkan adonan abu gosok yang menempel pada telur secara tradisional atau digosok secara manual menggunakan sabut stainless. Cara membersihkan adonan abu gosok yang membungkus telur asin secara tradisional memerlukan waktu yang lama bahkan melebihi jadwal yang sudah ditentukan dalam membersihkan adonan abu gosok yang tentunya berdampak pada tidak terpenuhinya kebutuhan pasar.
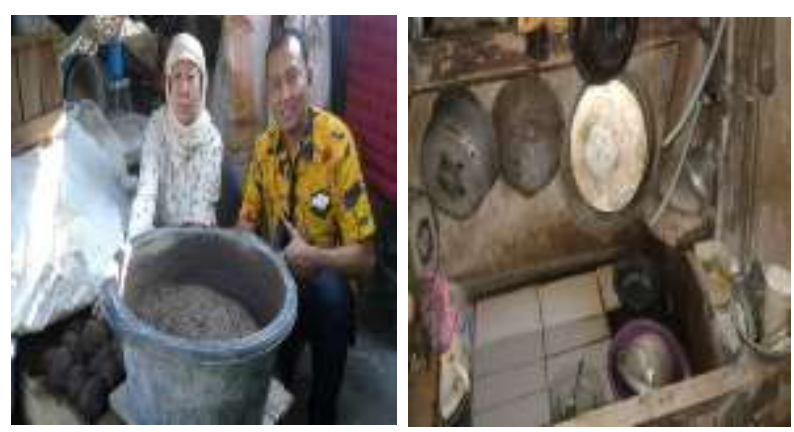

Gambar 1. Pembuatan dan pencucian telur asin secara tradisional

Tahap pencucian adonan abu gosok yang menempel pada cangkang bakal telur asin masih secara tradisional atau pencucian secara manual dengan cara di sikat menggunakan sikat stainless secara perlahan - lahan pada bagian abu gosok. 
Waktu yang diperlukan cukup lama dalam membersihkan adonan Abu Gosok yang menempel pada telur sehingga berdampak pada hilangnya konsumen telur asin. Tidak terpenuhinya pesanan konsumen mitra secara tepat waktu yang disebabkan lambatnya proses pencucian adonan abu gosok menimbulkan dampak negatif pada keberlangsungan usaha. Permasalahan yang terjadi pada mitra adalah kecilnya wadah yang dimiliki pada saat penyimpanan telur setelah di bungkus dengan adonan abu gosok dan lambatnya proses membersihkan adonan abu gosok yang menempel pada permukaan telur setelah proses pemeraman beberapa hari. Pembuatan telur asin menggunakan metode pemeraman yang dilakukan oleh mitra memerlukan waktu yang lama.

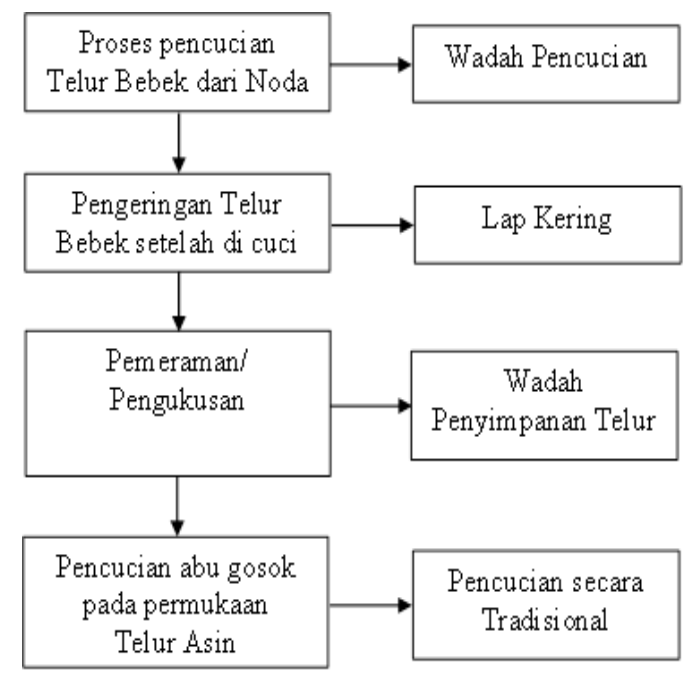

Gambar 2. Alur produksi telur asin pada mitra

\section{SUMBER INSPIRASI}

Peralatan untuk memproduksi telur asin yang diperlukan pengusaha dalam pembuatan telur asin merupakan solusi yang dilakukan agar pembuatan telur asin tidak memerlukan waktu yang lama. Selain itu, teknologi modern yang dibutuhkan untuk membersihkan adonan abu gosok yang menempel pada permukaan cangkang telur asin juga diperlukan untuk mengatasi permasalahan yang terjadi pada telur asin yang diproduksi.

\section{Metode Kegiatan}

Wadah yang dimiliki hanya dapat menampung 100 butir telur asin dalam satu kali produksi. Proses pembuatan telur asin masih menggunakan metode pemeraman yang memerlukan waktu yang lama yaitu : 15 hingga 21 hari dalam satu kali produksi. Setelah menerapkan proses pengasinan menggunakan metode mesin pembuat telur asin maka hanya memerlukan waktu maksimal 3 hari dengan kapasitas 100 sampai 200 butir telur dalam satu kali produksi.

Pencucian telur asin secara tradisional atau gosok menggunakan sikat stainless dengan kapasitas 50 butir telur memerlukan waktu hingga \pm 5 jam. Setelah menggunakan teknologi modern, waktu yang diperlukan untuk membersihkan adonan abu yang menempel pada telur kurang lebih 5 menit hingga 10 menit dengan kapasitas yang sama dan dapat dilakukan. Sumber daya manusia yang dimiliki mengalami kesulitan dalam penyusunan laporan keuangan, oleh karena itu perlunya pelatihan dan pembimbingan penyusunan laporan keuangan bagi usaha kecil dan menengah telur asin. Penting bagi mitra untuk mempertahankan peluang konsumen dengan mengikuti pelatihan tentang strategi pemasaran dalam menghadapi pesaing.

\section{KaRYa UTAMa}

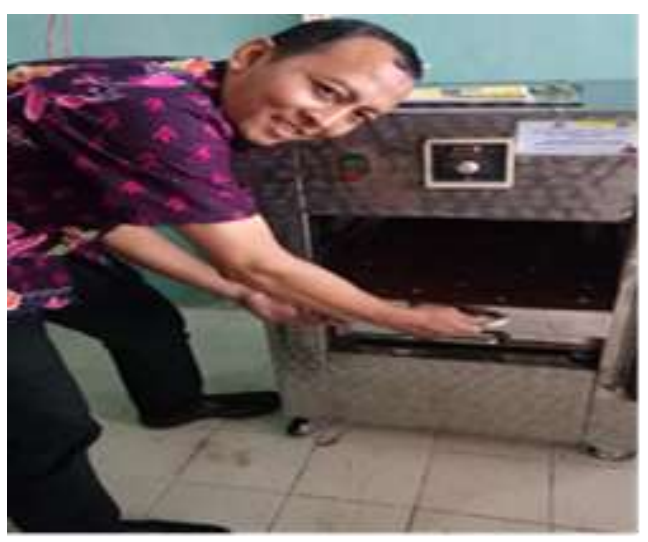

Gambar 3. Mesin Pembuat Telur Asin

Mesin pembuat telur asin yang digunakan untuk produksi telur asin mempermudah mitra karena 
dapat memproduksi dengan kapasitas yang besar dalam satu kali pembuatan mencapai 100 hingga 200 butir telur, selain kapasitas yang besar waktu yang diperlukan lebih singkat dibandingkan pembuatan secara tradisional yaitu; 3 hari. Mesin pembuat telur asin terbuat dari bahan plat stainless yang berukuran panjang $60 \mathrm{~cm}$, lebar $57 \mathrm{~cm}$ dan tinggi $110 \mathrm{~cm}$. Model mesin pembuat telur asin memiliki penyimpanan telur asin berbentuk rak yang terdiri dari 3 rak (gambar 3).

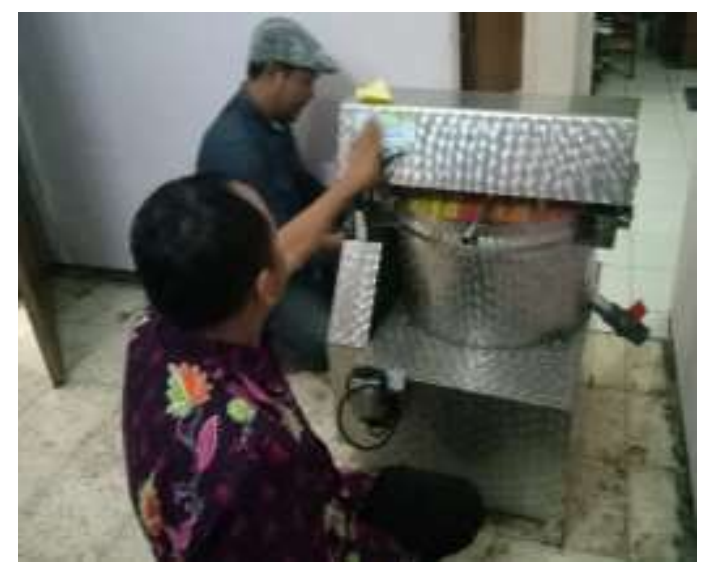

Gambar 4. Alat Pencuci Telur Asin

Mesin pencuci telur asin yang digunakan mitra dapat mempercepat proses pencucian abu gosok yang menempel pada cangkang telur. Pada saat proses pencucian telur asin memerlukan waktu lebih singkat di bandingkan pencucian secara tradisional. Mesin pencucian telur asin terbuat dari bahan plat stainless yang berukuran panjang $77 \mathrm{~cm}$, lebar $73 \mathrm{~cm}$ dan tinggi $85 \mathrm{~cm}$. Mesin pencuci telur asin dilengkapi penggerak dengan dinamo berukuran 1/4 PK yang berguna untuk memutar baling-baling pencuci yang berbentuk seperti kuas (gambar 4).

\section{ULASAN KARYA}

Keunggulan mesin Pembuat Telur Asin adalah proses pengasinan menggunakan metode mesin produksi telur asin hanya memerlukan waktu maksimal 3 hari dengan kapasitas 100 hingga 150 butir telur dalam satu kali produksi.
Keunggulan Mesin Pencuci Telur Asin adalah setelah menggunakan mesin pencuci, waktu yang diperlukan untuk membersihkan adonan abu yang menempel pada telur kurang lebih 5 menit hingga 10 menit dengan kapasitas yang sama.

\section{KESIMPULAN}

Berdasarkan analisis pelaksanaan kegiatan yang sudah berjalan bahwa proses produksi telur asin menggunakan mesin pembuat telur asin sangat membantu mitra untuk memenuhi permintaan konsumen. Produksi telur menggunakan mesin tersebut hanya memerlukan waktu 3 hari dengan kapasitas 100 hingga 150 butir telur artinya jika dibandingkan dengan pembuatan secara tradisional, pembuatan telur menggunakan mesin sangat membantu mitra guna meningkatkan pendapatan usaha. Selain tahap pembuatan telur asin, tahap pencucian adonan abu gosok yang menempel pada cangkang telur asin dengan menggunakan mesin pencuci sangat membantu, karena dengan alat tersebut proses pencucian telur menjadi lebih cepat hanya memerlukan waktu 5 hingga 10 menit dengan kapasitas 50 butir telur dalam satu kali pencucian. Pelatihan penyusunan laporan keuangan dan pembinaan strategi pemasaran berupa pelatihan manajemen strategi pemasaran dan kewirausahaan mempermudah mitra untuk mempertahankan pangsa pasar dan meningkatkan jumlah konsumen telur asin. Pelatihan yang dilaksanakan pada mitra dapat mengetahui kinerja sumber daya manusia pada mitra dan mengetahui peningkatan pendapatan usaha.

\section{DAMPAK DAN MANFAAT KEGIATAN}

Pelaksanaan program kemitraan masyarakat kelompok usaha kecil telur asin Kelurahan Mojolangu Kecamatan Lowokwaru memberikan dampak positif pada mitra. Inovasi proses produksi pada mitra berupa pembuatan dan pencucian menggunakan mesin dapat meningkatkan pendapatan 
bagi mitra karena dapat memenuhi permintaan konsumen telur asin dengan tepat waktu. Pelatihan pembinaan strategi pemasaran yang di laksanakan pada mitra dapat mempersiapkan mitra untuk menghadapi pesaing guna mempertahankan pangsa pasar bahkan dapat meningkatkan jumlah konsumen telur asin. Upaya untuk memaksimalkan program kemitraan masyarakat masih diperlukan, pendampingan secara berkelanjutan pada mitra guna meningkatkan skala usaha menjadi lebih besar.

\section{DAFTAR PUSTAKA}

1. Humam, P. "Bersama UKM Membangun Ekonomi Rakyat dan Lingkungan Hidup".

Medan: Fakultas Ekonomi USU.2012. 